\title{
The operating parameters of internal combustion engines in the road test
}

\begin{abstract}
A characteristic feature of internal combustion engines of a vehicle used in real operating conditions are frequent changes of the values of power in the powertrain. The analysis of the results of the road test through a measurement of parameters of engine (CAN BUS) in a passenger car proves, that the changes of parameters and engine power are frequent. Particularly under the conditions of urban test-drive their frequency, range and dynamics is significant. As a result the engine speed, throttle opening and fuel consumption are not constant, as in the case of measurements realized under stationary conditions on an engine test stand, while determining of the engine speed characteristic. The paper presents the analysis of the engine parameters determined based on on-road tests rather than laboratory tests.
\end{abstract}

Key words: CAN BUS, parameters of work, internal combustion engine

\section{Parametry pracy silnika spalinowego $\mathrm{w}$ teście drogowym}

Cecha charakterystyczna samochodowego silnika spalinowego poruszajacego się w rzeczywistych warunkach ruchu na drodze sa częste zmiany mocy w ukladzie napędowym. Analiza wyników rejestracji jazdy drogowe przez pomiar parametrów silnika na magistrali CAN BUS w samochodzie osobowym dowodzi, że zmiany parametrów i mocy silnika sq częste. Szczególnie w warunkach jazdy miejskiej ich częstotliwość, zakres i dynamika zmian jest duża. W rezultacie prędkość obrotowa silnika, uchylenie przepustnicy i zużycie paliwa nie sq stałe, jak przy pomiarach wykonywanych w warunkach statycznych na hamowni silnikowej. W artykule przedstawiono analizę parametrów pracy silnika spalinowego określonych nie na podstawie wyników badań stanowiskowych, ale na podstawie wyników pomiarów zrealizowanych podczas jazd drogowych.

Słowa kluczowe: parametry pracy, silnik spalinowy, magistrala CAN BUS

\section{Introduction}

In the present state of technology, a lot of attention is paid to analysis of engine parameters in real conditions on the road in order to ensure that the then obtained course is devoid of any interferences $[1,2,4,5]$. However, a combustion engine is a dynamic object and its operation with variable speed is accompanied by energy accumulation processes. The most important processes of accumulation are connected with the flow of thermal and mechanical energy of movable masses of the crankshaft-piston assembly of the engine. The abovementioned phenomena affect the changes of the operating parameters of engine in the powertrain of a vehicle in real conditions on the road. In modern passenger vehicles, the entire powertrain is subject to constant evolution manifested by better indicators of operation resulting from structural improvement of known solutions. The new solutions have to consider protection of natural environment against the effects of the development of the automotive industry being one of the main tasks that a man has to face in the $21^{\text {st }}$ century. However, we have to remember about the basic functions of the engine and powertrain of a passenger vehicle involving generation of the engine torque as appropriate for driving conditions that is translated into a respective driving force resulting from the relationship (1):

$$
\mathrm{F}_{\mathrm{n}}=\frac{\mathrm{M}_{\mathrm{o}} \mathrm{i}_{\mathrm{c}} \eta_{\mathrm{UN}}}{\mathrm{r}_{\mathrm{d}}} \leq\left(\mathrm{F}_{\mathrm{n}}\right)_{\mathrm{gr}}
$$

\section{Wstęp}

Przy obecnym stanie techniki bardzo dużo uwagi poświęca się analizie parametrów silnika w warunkach rzeczywistego ruchu drogowego, tak aby ich uzyskany ich przebieg był pozbawiony wszelkich zakłóceń $[1,2,4,5]$. Jednak silnik spalinowy jest obiektem dynamicznym, któremu podczas pracy ze zmienną prędkością towarzyszą procesy akumulacji energii. Najważniejsze procesy akumulacji są związane z przepływem energii cieplnej i energii mechanicznej ruchomych mas układu korbowo-tłokowego silnika. Wymienione zjawiska oddziaływują na zmianę parametrów pracy silnika w układzie napędowym samochodu w rzeczywistych warunkach ruchu. W nowoczesnych samochodach osobowych cały układ napędowy podlega nieustannej ewolucji, przejawiającej się lepszymi wskaźnikami pracy, wynikającymi z konstrukcyjnego doskonalenia znanych rozwiązań. Nowe rozwiązania muszą mieć na uwadze ochronę środowiska naturalnego przed skutkami rozwoju motoryzacji; jest to jedno z głównych zadań, jakim musi sprostać człowiek XXI wieku. Nie można jednak zapomnieć o podstawowej funkcji silnika i układu napędowego samochodu osobowego, polegającej na generowaniu odpowiedniego do warunków ruchu momentu obrotowego silnika, który przekłada się na odpowiednią siłę napędową zgodnie z zależnością (1).

Jej przebieg, szczególnie w procesie rozpędzania, ma istotne znaczenie dla bezpieczeństwa ruchu. Jest to w sensie dynamicznym ekstremalny stan ruchu przyspieszonego, od startu aż do osiągnięcia określonej prędkości docelowej, 
The course of the driving force, in particular, during acceleration, is significant for traffic safety. From a dynamic point of view, it is an extreme state of accelerated drive from the start until attainment of a specified target speed and most often with devices controlling feeding of fuel into the combustion engine set to full dosing. According to literature $[4,9]$, the share of acceleration phase in normal operating conditions constitutes a considerable part of drive time, i.e. as much as $42 \%$ of the total time of urban driving and $26 \%$ of extra urban driving. According to [9], change of the position of the UN actuators is made from 120 to 350 times per hour, which corresponds to 6-17 changes on average per one kilometer of drive. In official certification tests of vehicles adopted by the U.S. Environmental Protection Agency, according to EPA cycle, the acceleration phase constitutes $39.7 \%$ of the total drive time of a vehicle in urban conditions and $33 \%$ in extra urban conditions.

Whereas basic resistance forces are determined unambiguously by structural parameters of a vehicle, its acceleration ability depends directly on the operating parameters of the engine and transmission system. The analysis of the operating parameters of the engine is the object of this study.

\section{Variability of driving conditions of a vehicle}

During acceleration, when the powertrain is in temporary conditions (dynamic condition) and adopted constant values are variable (which relates to the traction coefficient, rolling resistance coefficient, variable dynamic radius, efficiency of the drive transmission system), the indicated momentary parameters of the engine in real conditions on the road have to be measured precisely and they differ from the parameters obtained in stationary conditions $[3,6,7,8]$. The situation is additionally complicated by the surrounding conditions that force constant changes of the engine power fed to the wheels, which is indirectly shown in the charts presented in Fig. 1.

Measurement of the operating parameters of the engine in variable speed conditions requires solving a lot of problems that relate, in particular, to the availability of all measured parameters in real time.

\section{Testing tools and tested object}

Due to diversified structure of engines in the powertrain of a vehicle, the Chair of Road and Agricultural Vehicles of

a)

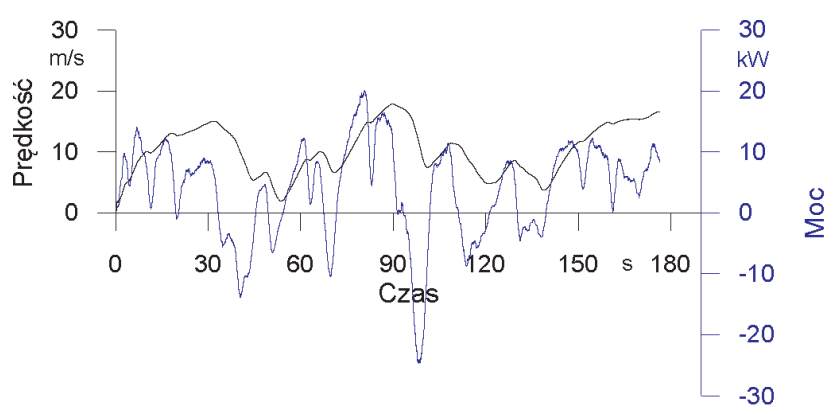

najczęściej przy ustawieniu urządzeń sterujących dopływem paliwa do silnika spalinowego na pełne dawkowanie. Jak podaje literatura [4, 9], udział fazy rozpędzania w warunkach normalnej eksploatacji stanowi znaczną część czasu jazdy, tj. aż 42\% łącznego czasu jazdy miejskiej i $26 \%$ jazdy drogowej. Według [9] zmiana położenia elementów sterujących UN dokonywana jest 120 do 350 razy w ciągu godziny, co odpowiada średnio 6 do 17 zmianom na kilometr przebytej drogi. W badaniach homologacyjnych pojazdów, przyjętych przez Amerykańską Agencję Ochrony Środowiska (U.S. Environmental Protection Agency), według cyklu EPA, faza przyspieszania to $39,7 \%$ łącznego czasu jazdy pojazdu w warunkach miejskich i 33\% w warunkach pozamiejskich.

Zważywszy, że siły oporów podstawowych są jednoznacznie determinowane parametrami konstrukcyjnymi samochodu, jego zdolność przyspieszania zależy bezpośrednio od parametrów pracy silnika i układu przeniesienia napędu. Analiza parametrów pracy silnika jest przedmiotem niniejszego opracowania.

\section{Zmienność warunków ruchu samochodu}

Podczas przyspieszania, gdy układ napędowy jest w warunkach przejściowych (stan dynamiczny), a przyjęte wartości stałe są zmienne (dotyczy to współczynnika przyczepności, współczynnika oporu toczenia, zmiennego promienia dynamicznego, sprawności układu przeniesienia napędu), wyznaczone chwilowe parametry silnika w rzeczywistych warunkach ruchu wymagają precyzyjnego pomiaru i różnią się od parametrów uzyskanych w warunkach ustalonych [3, $6,7,8]$. Sytuację dodatkowo komplikuje otoczenie, które wymusza ciągłe zmiany mocy silnika doprowadzonej do kół; pośrednio uwidaczniają to wykresy przedstawione na rys. 1.

Pomiar parametrów pracy silnika w warunkach zmiennej prędkości wymaga rozwiązania wielu problemów, które dotyczą przede wszystkim dostępności mierzonych parametrów w czasie rzeczywistym.

\section{Narzędzia badawcze i obiekt badań}

Ze względu na zróżnicowaną konstrukcję silników w układzie napędowym samochodu, w Katedrze Pojazdów Drogowych i Rolniczych Politechniki Opolskiej zbudowano przenośny system rejestracji danych pomiarowych o nazwie

Fig. 1. The example temporary course of the speed and the power for the following traffic: a) urban, b) extra urban

Rys. 1. Przykładowy czasowy przebieg prędkości jazdy i mocy w warunkach ruchu: a) miejskiego, b) pozamiejskiego 
the Opole University of Technology developed a portable measurement data recording system referred to as PAAF2 (Power Acceleration And Force). The system is used for recording of operating parameters of the engine and kinematic values characterizing the drive of the tested vehicle. The application was created with the use of LabView program. The main window of the application enabling the operation of the software is presented in Fig. 2.

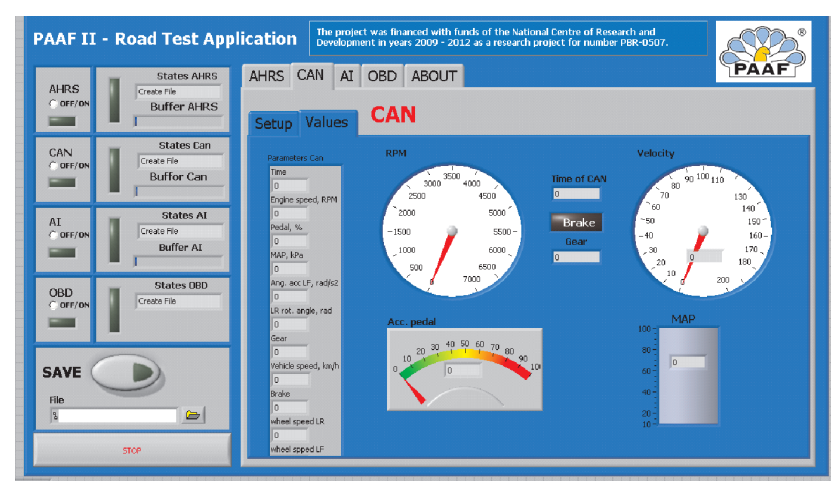

Fig. 2. The Main window of PAAF2

Rys. 2. Główne okno sterujace programu PAAF2

The system enabled recording of operating parameters of the engine and kinematic parameters of the drive of a vehicle in the field of time from the following measurement systems:

- from the diagnostic system OBD II:

- engine speed in rev./min.,

- throttle opening, $\%$,

- vacuum in the intake manifold, $\mathrm{kPa}$,

- linear speed of the vehicle, $\mathrm{km} / \mathrm{h}$,

- from analogue and digital measurement card NI 6212 used for measurement of:

- $\quad$ speed $[\mathrm{km} / \mathrm{h}]$ and road [m] from Corrsys Datron L350 optical head,

- throttle opening, $\%$,

- acceleration pedal, $\%$,

- from the system of acceleration and multifunctional sensor 3DM-GX3-25:

- magnetic directions of the axis $\mathrm{X}, \mathrm{Y}, \mathrm{Z}$,

- acceleration of the axis $\mathrm{X}, \mathrm{Y}, \mathrm{Z}, \mathrm{m} / \mathrm{s}^{2}$,

- rotating angle of measurement axis, $\mathrm{X}, \mathrm{Y}, \mathrm{Z}$, radius,

- from the drive network of data transmission based on CAN

BUS, including, among others:

- engine speed, rev./min.,

- throttle opening, $\%$,

- acceleration pedal, \%

- vacuum in the intake manifold, $\mathrm{kPa}$,

- acceleration of the wheel, $\mathrm{rad} / \mathrm{s}^{2}$,

- wheel distance covered, radius

- gear number,

- linear speed of the vehicle, $\mathrm{km} / \mathrm{h}$,

- brake pedal,

- charging pressure, $\%$,

- temperature, ${ }^{\circ} \mathrm{C}$,
PAAF2 (ang. Power Acceleration And Force). System ten służy do rejestracji parametrów pracy silnika spalinowego oraz wielkości kinematycznych charakteryzujących ruch badanego samochodu. Aplikacja została napisana przy użyciu programu LabView. Główne okno aplikacji, umożliwiające obsługę programu, przedstawiono na rys. 2 .

System umożliwił rejestrację parametrów pracy silnika oraz kinematycznych ruchu samochodu w dziedzinie czasu, z następujących układów pomiarowych:

- z pokładowego systemu diagnostycznego OBD II:

- prędkość obrotową silnika, obr/min,

- uchylenie przepustnicy, \%,

- podciśnienie w kolektorze dolotowym, $\mathrm{kPa}$,

- prędkość liniową pojazdu, $\mathrm{km} / \mathrm{h}$,

- z analogowo-cyfrowej karty pomiarowej NI 6212, za pomocą której mierzono:

- prędkość $[\mathrm{km} / \mathrm{h}$ ] oraz drogę [m] z głowicy optycznej Corrsys Datron L350,

- uchylenie przepustnicy, \%,

- pedał przyspieszenia, $\%$,

- z układu pomiaru przyspieszenia $\mathrm{z}$ wielofunkcyjnego czujnika 3DM-GX3-25:

- kierunki magnetyczne osi X, Y, Z,

- przyspieszenie osi $\mathrm{X}, \mathrm{Y}, \mathrm{Z}, \mathrm{m} / \mathrm{s}^{2}$,

- kąt obrotu osi pomiarowych, X, Y, Z, rad,

- z pokładowej sieci transmisji danych opartej na magistrali CAN BUS m.in:

- prędkość obrotową silnika, obr/min,

- uchylenie przepustnicy, $\%$,

- pedał przyspieszenia, \%

- podciśnienie w kolektorze dolotowym, $\mathrm{kPa}$,

- przyspieszenie koła, $\mathrm{rad} / \mathrm{s}^{2}$,

- przebytą drogę koła, rad

- numer biegu,

- prędkość liniową pojazdu, km/h,

- pedał hamulca,

- ciśnienie doładowania, \%,

- temperaturę, ${ }^{\circ} \mathrm{C}$,

- obciążenie, \%,

- strumień paliwa, $\mathrm{ml} / \mathrm{suw}$.

Dzięki elastycznemu systemowi pomiarowemu aplikacja PAAF2 umożliwiała swobodny wybór sposobu zapisu parametrów w zależności od użytego pojazdu badawczego. Odczyt parametrów z systemu OBD II raz skonfigurowany umożliwiał odczyt parametrów, niezależnie od badanego samochodu. W badaniach drogowych wykorzystano samochody osobowe różnych marek, z których każdy charakteryzował się odmienną konstrukcją silnika i układu napędowego, tj. Citroen C5 V6, Mercedes-Benz B180, Seat EXEO 2.0 TSI, Fiat Punto II 1.2 16V, Hyundai i35, Seat Ibiza 1.4 MPI.

\section{Parametry pracy silnika $w$ teście drogowym}

Jak już wspomniano, proces przyspieszania z maksymalną intensywnością jest ekstremalnym stanem pracy dla silnika i charakteryzuje się niepowtarzalnością oraz występowaniem losowych zakłóceń. Poniżej przedstawiono (rys. 3) zarejestrowany przykładowy profil prędkości podczas 
- load, \%,

- fuel stream, $\mathrm{ml} /$ stroke.

Owing to the flexible measurement system, PAAF2 application made it possible to select freely a method of recording of parameters depending on the testing vehicle used. Once configured, the readout of parameters from the OBD II system made it possible to read parameters, regardless of the tested vehicle. In road tests, various makes of vehicles were used and each of them was characterized by different structure of the engine and powertrain, i.e. Citroen C5 V6, Mercedes-Benz B180, Seat EXEO 2.0 TSI, Fiat Punto II 1.2 16V, Hyundai i35, Seat Ibiza 1.4 MPI.

\section{Operating parameters of the engine during on- road test}

As it has already been mentioned, the process of acceleration with maximum intensity is an extreme operating condition of the engine and it is characterized by uniqueness and presence of random interferences. The figure below (Fig. 3) presents an example of the recorded speed profile during the acceleration of Citroen C5 passenger vehicle with PAAF2.

The above chart compares the recorded course of linear speed of the vehicle during the process of acceleration with the use of three methods. They relate to the recording of parameters from:

- the diagnostic network OBD II

- the network of data transmission CAN

- direct measurement, e.g. Datron L350 sensor.

Four parameters were recorded from the drive diagnostic network and the parameters constitute a valuable source of information about, what was happening with the engine during the process of acceleration. Despite standardization of OBD II transmission protocols in this field, the main problem connected with the operation of the system is the lack of transmission in real time. We record a signal with low resolution and the signal is transmitted with a delay. As a result, the recorded signal is not continuous. Another problem connected with this measurement involves communication of OBD II standard that is based upon queries and feedback, where the source of query is an external device and feedback is given by particular controllers of the drive network. Thus, there is also a time shift between the two signals recorded in this system. The number of signals recorded affects the obtained speed of communication and, in this case, sampling frequency of $2 \mathrm{~Hz}$ was obtained for one signal.

The use of information from the drive system of data transmission and CAN BUS is a source of direct information transmitted between controllers of the drive network of the vehicle with transmission speed depending on a vehicle make (the speed for Citroen C5 was $500 \mathrm{Kbit} / \mathrm{s}$, which enables recording of transmitted parameters with a sampling frequency of $65 \mathrm{~Hz}$ ). The main problem connected with procesu rozpędzania dla samochodu osobowego Citroen C5 systemem PAAF2.

Na powyższym wykresie porównano zarejestrowany przebieg prędkości liniowej samochodu podczas procesu przyspieszania trzema metodami. Dotyczą one zapisu parametrów z:

- pokładowej sieci diagnostycznej OBD II

- sieci transmisji danych CAN

- bezpośredniego pomiaru np. czujnik Datron L350.

Z pokładowej sieci diagnostycznej rejestrowano cztery parametry, które są źródłem cennych informacji o tym, co działo się z silnikiem podczas rozpędzania. Pomimo standaryzacji protokołów transmisji OBD II w tej dziedzinie, głównym problemem związanym z działaniem tego systemu jest brak transmisji w czasie rzeczywistym. Rejestrujemy sygnał o niskiej rozdzielczości przesyłany z opóźnieniem. W efekcie zarejestrowany sygnał nie jest ciągły. Kolejnym problemem związanym z tym pomiarem jest komunikacja

standardu OBD II, która opiera się na zapytaniach i odpowiedziach, przy czym źródłem zapytań jest urządzenie zewnętrzne, a odpowiedzi udzielają poszczególne sterowniki sieci pokładowej, a więc istnieje również przesunięcie czasowe pomiędzy dwoma rejestrowanymi sygnałami w tym układzie. Ilość rejestrowanych sygnałów wpływa na uzyskaną szybkość komunikacji, w tym przypadku uzyskano częstotliwość próbkowania $2 \mathrm{~Hz}$ dla jednego sygnału.

Wykorzystanie informacji z pokładowego systemu transmisji danych, magistrali CAN BUS, jest źródłem bezpośrednich informacji przekazywanych pomiędzy sterownikami sieci pokładowej samochodu z prędkością transmisji zależną od marki samochodu (dla Citroena C5 prędkość wynosiła $500 \mathrm{Kbit} / \mathrm{s}$, co umożliwia zapis transmitowanych parametrów z częstotliwością próbkowania $65 \mathrm{~Hz}$ ). Głównym problemem związanym z dostępem do informacji przesyłanych w obrębie sieci CAN jest nieznajomość szczegółowego protokołu transmisji, tj. na jakim adresie ID transmitowana jest jaka zmienna i jaki został zastosowany sposób kodowania infor- 
access to information transmitted within CAN network is the unknown detailed transmission protocol, i.e. to which ID address a given variable is transmitted and what method of coding of information was used. Particular data is transmitted in 8 byte base 16 system and the information is transmitted on one or two bytes. The scope of change for one byte is from 0 to 255 and for two bytes - from 0 to 65,535 . The number of recorded signals does not affect the obtained frequency of record.

Direct measurement requires using additional measurement equipment, e.g. Datron L350 optical sensor and measurement card manufactured, for example, by National Instrument. Additionally, measurement with the use of this method requires a modification of the vehicle for the purposes of installation of additional sensors or delivery of appropriate measurement points.

Differences between indications of throttle opening values (Fig. 4) are small in the case of the second and third method. However, the method of measurements based upon OBD II system is characterized by intermittence (step course) and time delay.

The greatest opportunities as regards selection of parameters and transmitted quantities were offered by the method based upon recording of information transmitted between controllers of CAN BUS data transmission network.

The number of various manufacturers of vehicles and systems used for the creation of CAN drive data transmission network causes that, despite standardization, they differ in details of workmanship and are not fully compatible. This relates both to the physical aspect of data transmission, i.e. level of voltage, forming of the transmission frame, network structure or transceiver system as well as the IT aspect. Despite comprehensive service documents, information concerning protocols of transmission used in CAN buses is perfunctory or brief [10]. The documents describe in detail diagnostic processes on the basis of the standard of OBD II data transmission. However, it is difficult to obtain direct access to parameters of the data bus. A considerable part of vehicle manufacturers conducts CAN bus to OBD II diagnostic connection onto 6 and 14 pins, however, its is often impossible to obtain direct access to parameters of the bus. In many cases, parameters are transmitted through a respective CAN bus controller, which cooperates with OBD II diagnostic system and transmits appropriate data prepared in this standard.

Generally, we may distinguish between several methods of communications between CAN network controllers and external devices reading data via OBD II connection:

- direct coded access to CAN bus is only possible for devices programmed by technical support of a given make,

- direct open communication - in this case, CAN network junctions are conducted in the diagnostic socket,

- indirect access with the use of OBD II standard. If CAN bus controller states that a diagnostic device is not manu- macji. Poszczególne dane są transmitowane w układzie 8 bajtów w systemie szesnastkowym, przy czym informacje są przesyłane na jednym lub dwóch bajtach. Zakres zmiany na jednym bajcie wynosi od 0 do 255 , a na dwóch od 0 do 65 535. Liczba rejestrowanych sygnałów nie wpływa na uzyskaną częstotliwość zapisu.

Bezpośredni pomiar wymaga zastosowania dodatkowych urządzeń pomiarowych, np. czujnika optycznego Datron L350 i karty pomiarowej np. firmy National Instrument. Ponadto pomiar tą metodą wymaga modyfikacji samochodu w celu montażu dodatkowych czujników lub wykonania odpowiednich punktów pomiarowych. 
Table 1. The method of connection of SYS-TEC interface to a vehicle

Tabela 1. Sposób podłaczenia interfejsu SYS-TEC do samochodu

\begin{tabular}{|c|c|c|c|}
\hline Make/Type/marka/typ & Fuel type/typ paliwa & UPN & Method of connection/sposób podtaczenia \\
\hline Hyundai i35 & gasoline/benzyna & manual/manualny & OBD II socket/gniazdo \\
\hline Hyundai i10 & gasoline & manual & OBD II socket \\
\hline Seat Exeo 2.0 TSI & gasoline & manual & OBD II socket \\
\hline Seat Ibiza 1.4 MPI & gasoline & manual & CAN bus directly/bezpośrednia magistrala \\
\hline Citroen C5 & gasoline & automatic & CAN bus directly \\
\hline Citroen C6 & diesel & manual & CAN bus directly \\
\hline Mercedes B180 & diesel & manual & CAN bus directly \\
\hline Fiat Punto II & gasoline & automatic & OBD II socket \\
\hline Fiat Stillo & diesel & manual & CAN bus directly \\
\hline VW Golf & gasoline & manual & \\
\hline
\end{tabular}

factured by the company, data will be transmitted to the reader via OBD II standard.

However, it is also possible to read data transmitted from CAN bus by connecting directly with the bus line creating another junction point of the network. Reading of data from CAN bus has a lot of strong points. The most important strong point in terms of the analysis of operating parameters of the engine is transmission in real time below $10 \mathrm{~s}$, which is several dozen times faster compared with readouts in OBD II standard. A device manufactured by SYS-TEC was used for recording of parameters from CAN bus. The device is used by the Chair of Road and Agricultural Vehicles of Opole University of Technology.

Due to diversification of vehicles, Table 1 presents a method of connection of SYS-TEC.

It is difficult to identify the data transmitted in this type of measurement, i.e. separate a protocol of transmission of data field and, subsequently, decode the same. It should be emphasized that data fields transmitted via CAN bus are different for different makes and they change even within one make, which depends on the version and equipment of a given model. Both identification device of the controller as well as scope of data transmitted are subject to change. For example, inclination of the throttle in Seat Ibiza 1.4 MPI is at the address of $280 \mathrm{~h}$ (hexagonally) on byte 4 and it is at the same address in Seat Exeo 2.0 TSI, whereas in Citroen $\mathrm{C} 5$, this information is at the address of 208h, byte 6 .

Testing of the process of acceleration with fourth gear used (Fig. 5) and maximum intensity is characteristic of a passing power test. The acceleration was realized from the engine speed of $1500 \mathrm{rev} . / \mathrm{min}$. and in the initial phase (approx. $22 \mathrm{~s}$ ) we may observe considerable growth of fuel consumption. Despite maintaining of the throttle opening in the maximum position, fuel consumption was growing more slowly up to the engine speed of $5000 \mathrm{rev} / \mathrm{min}$., i.e. up to the speed characteristic of maximum power.
II na piny 6 i 14, jednak bezpośredni dostęp do parametrów magistrali mimo to często jest niemożliwy. W wielu przypadkach parametry są przekazywane przez odpowiedni sterownik magistrali CAN, który współpracuje z układem diagnostycznym OBD II i przekazuje odpowiednio przygotowane dane w tym standardzie.

Ogólnie można wyróżnić kilka sposobów komunikacji pomiędzy sterownikami sieci CAN a urządzeniami zewnętrznymi odczytującymi dane przez złącze OBD II:

- bezpośredni kodowany, wówczas dostęp do magistrali CAN mają tylko urządzenia oprogramowane przez zaplecze techniczne dla danej marki,

- bezpośredni otwarty, wówczas $\mathrm{w}$ gnieździe diagnostycznym są wyprowadzone węzły sieci CAN,

- pośredni za pomocą standardu OBD II. Jeśli sterownik magistrali CAN stwierdzi, że urządzenie diagnostyczne nie jest firmowe, to dane do czytnika będą przekazane przez standard OBD II.

Jednak można również odczytać transmisje z magistrali CAN przez bezpośrednie podłączenie się do linii magistrali, tworząc następny punkt węzłowy sieci. Odczyt danych z magistrali CAN ma wiele zalet, spośród których najistotniejszą z punktu widzenia analizy parametrów pracy silnika jest transmisja w czasie rzeczywistym z czasem poniżej 10 ms, co jest kilkadziesiąt razy szybciej w porównaniu z odczytem w standardzie OBD II. Do rejestracji parametrów z magistrali CAN wykorzystano urządzenie firmy SYS-TEC,

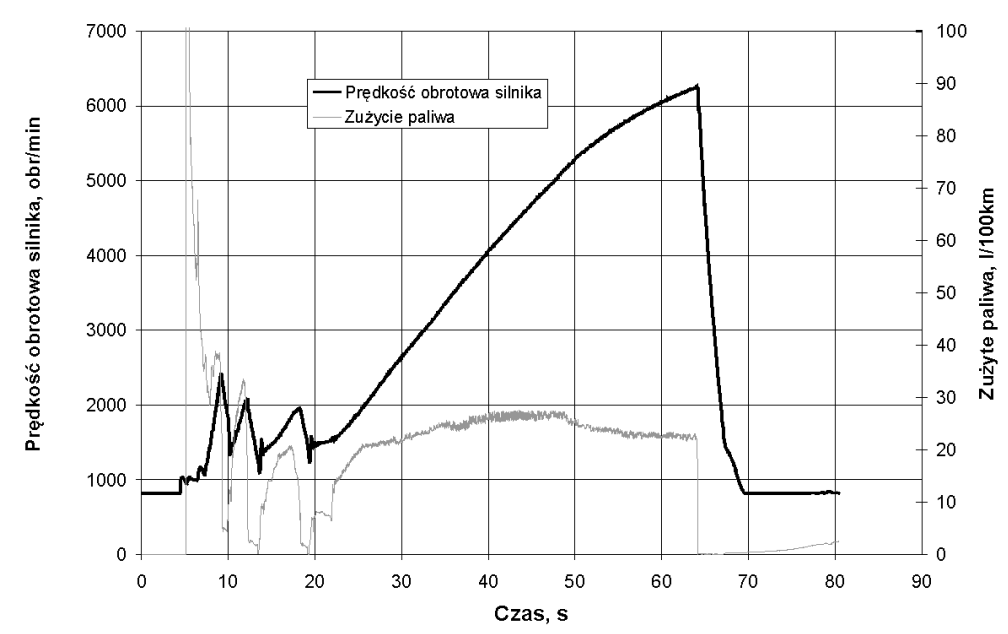

Fig. 5. The change of consumption of fuel and the engine speed during acceleration of Seat Exeo 2.0 TSI

Rys. 5. Zmiany zużycia paliwa i prędkości obrotowej silnika podczas przyspieszania samochodu Seat Exeo 2.0 TSI 


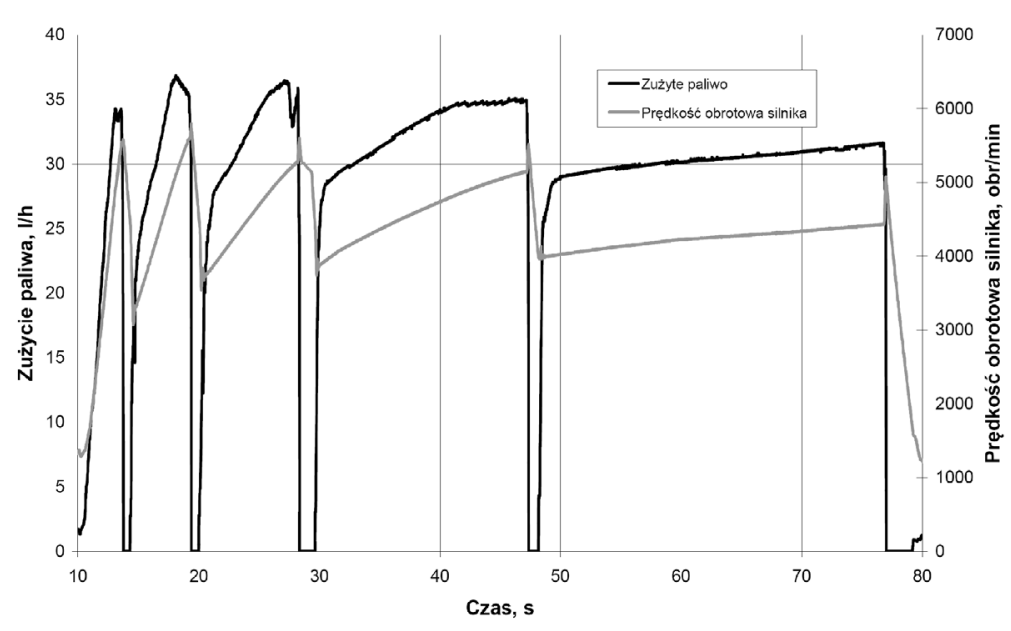

Fig. 6. The change of consumption of fuel and the engine speed during acceleration of

Rys. 6. Zmiany zużycia paliwa i prędkości obrotowej silnika podczas przyspieszania samochodu Seat Ibiza 1.4 MPi

In the case of acceleration of a vehicle (Fig. 6) using gears of maximum acceleration intensity, the throttle opening is set to maximum intensity and the value of the fuel consumed in time depends on the engine speed (Fig. 7).

Fuel consumption in time using of individual gears is directly proportional to the engine speed.

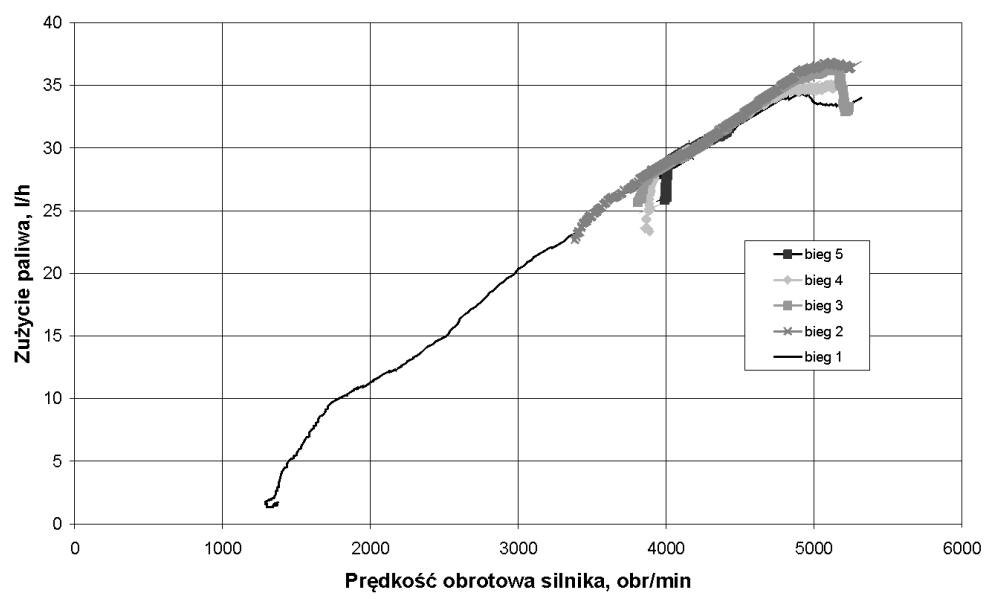

Fig. 7. The change of consumption of fuel as a function of the engine speed during acceleration of Seat Ibiza 1.4 MPi

Rys. 7. Zmiany zużycia paliwa w funkcji prędkości obrotowej silnika podczas przyspieszania samochodu Seat Ibiza 1.4 MPi Seat Ibiza 1.4 MPi

które znajduje się na wyposażeniu Katedry Pojazdów Drogowych i Rolniczych Politechniki Opolskiej.

Z uwagi na zróżnicowanie samochodów w tabeli 1 przedstawiono sposób podłączenia urządzenia SYS-TEC.

Trudnością $\mathrm{w}$ tego typu pomiarze jest identyfikacja przesyłanych danych, tj. wyseparowanie z protokołu transmisji pola danych, a następnie jego dekodowanie. Należy podkreślić, iż pola danych przesyłane magistralą CAN są różne dla różnych marek, a nawet w obrębie jednej marki pola te też ulegają zmianie, a uzależnione jest to od wersji i wyposażenia danego modelu. Zmianie podlega zarówno identyfikator sterownika, jak również zakres przesyłanych danych. Dla przykładu uchylenie przepustnicy w samochodzie Seat Ibiza 1.4 MPI jest na adresie 280h (heksagonalnie) na bajcie 4, na tym samym adresie jest w samochodzie Seat Exeo 2.0 TSI, natomiast w samochodzie Citroen C5 jest ta informacja na adresie $208 \mathrm{~h}$ na bajcie 6 .

Badanie procesu przyspieszania na biegu czwartym (rys. 5), z maksymalną intensywnością, jest charakterystyczne dla próby elastyczności. Rozpędzanie realizowano od prędkości obrotowej silnika $1500 \mathrm{obr} / \mathrm{min}$ i w początkowej fazie (ok. 22 s) zaobserwować można znaczący wzrost zużycia paliwa. Mimo utrzymywania uchylenia przepustnicy w położeniu maksymalnym (100\% otwarcie), zużycie paliwa narasta wolniej do prędkości obrotowej silnika 5000 obr/ min, a więc do prędkości charakterystycznej dla mocy maksymalnej

W sytuacji przyspieszania samochodu (rys. 6) przez biegi z maksymalną intensywnością, uchylenie przepustnicy jest ustawione na maksymalną intensywność, a wartość zużytego paliwa w czasie jest uzależniona od prędkości obrotowej silnika (rys. 7).

Czasowe zużycie paliwa na poszczególnych biegach jest wprost proporcjonalne do prędkości obrotowej silnika.

Z przedstawionych wykresów wynika, że pomiar parametrów pracy silnika $z$ sieci transmisji danych, magistrali CAN BUS, w stanach dynamicznych pozwala na przeprowadzenie ich analizy.

It results from the above charts that the measurement of the operating parameters of the engine from data transmission network and CAN BUS makes it possible to analyze the parameters in dynamic conditions.

\section{Conclusions}

It results from the operating parameters of the engine in real (dynamic) conditions on the road that it is possible to record the parameters from the data transmission network and CAN BUS and this method of recording has a lot of

\section{Wnioski}

Z pomiarów parametrów pracy silnika w rzeczywistych (dynamicznych) warunkach ruchu wynika, że rejestracja tych parametrów z sieci transmisji danych, magistrali CAN BUS, jest możliwa, a metoda rejestracji ma wiele zalet. Jako najważniejsze należy wymienić: rejestrację parametrów pracy silnika w czasie rzeczywistym, dostępność do wielu parametrów jednocześnie oraz uniwersalność. Tę metodę rejestracji można stosować $\mathrm{w}$ różnych samochodach, bez konieczności montażu dodatkowych urządzeń czy kosztow- 
strong points. Most significant strong points include the recording of operating parameters of the engine in real time, availability of numerous parameters at the same time and versatility of the parameters. This method of recording may be used in various vehicles without the need of developing additional equipment or expensive apparatuses and the recorded parameters are characterized by good signal dynamics, which makes it possible to analyze them freely. However, recording of operating parameters of the engine from OBD II diagnostic networks is burdened with a considerable delay and phase shift of the recorded parameters as well as limited speed of recording 1 .

The main weak point of the method is the lack of detailed protocols of transmission of CAN BUS.

The study was delivered as part of the project funded by the National Center of Research and Development in the years 2009-2012 as a development project No. N R10 005906.

Paper reviewed nej aparatury, a rejestrowane parametry odznaczają się dobrą dynamiką sygnału, co pozwala na swobodną ich analizę. Natomiast rejestracja parametrów pracy silnika z sieci diagnostycznych OBD II jest obarczona znacznym opóźnieniem i przesunięciem fazowym rejestrowanych parametrów przy ograniczonej ich prędkości zapisu.

Główną wadą jest brak dostatecznie opisanych szczegółowych protokołów transmisji magistrali CAN BUS.

Praca została wykonana $w$ ramach projektu sfinansowanego z funduszu Narodowego Centrum Badań i Rozwoju $w$ latach 2009-2012 jako projekt rozwojowy o numerze $N$ R10 005906.

\section{Nomenclature/Skróty i oznaczenia}

$\begin{array}{ll}\mathrm{F}_{\mathrm{n}} & \text { driving force/siła napędowa, } \mathrm{N} \\ \mathrm{F}_{\mathrm{b}} & \text { inertia force/siła bezwładności, } \mathrm{N} \\ \mathrm{F}_{\mathrm{t}} & \text { rolling resistance force/siła oporu toczenia } \mathrm{N} \\ \mathrm{M}_{\mathrm{o}} & \text { torque/moment obrotowy, } \mathrm{N} \cdot \mathrm{m} \\ \mathrm{i}_{\mathrm{c}} & \text { total transmission/przełożenie całkowite } \\ \mathrm{r}_{\mathrm{d}} & \text { dynamic radius/promień dynamiczny, } \mathrm{m} \\ \eta_{\mathrm{UN}} & \text { efficiency of the powertrain/sprawność układu napędowego } \\ \text { PAAF } & \text { Power Acceleration And Force/moc, przyspieszenie i siła }\end{array}$

\section{Bibliography/Literatura}

[1] Deneuville C., Streib H.M.: Electronic throttle control: contribution in engine management systems, 5th International Congress EAEC, Strasbourg 1995, nr SIA 9506A29.

[2] Gerhardt J., Benninger N., Heb W.: Torque-based system structure of an electronic engine management system (ME7) as a new base for drivetrain systems, FISITA'98, 1998, nr F98T624.

[3] Jantos J., Brol S., Mamala J.: Problems in assessing road vehicle drivability parameters determined with the aid of accelerometer, SAE 2007 Word Congress, April 6 - 19 2007, USA, Detroit, Vehicle Diagnostic SP-2137, nr 2007-01-1473.

[4] Kwark J., Jeon CH., Changy Y.: A Study on the Analysis and Evaluation of Transient Performance in MPI gasoline Engine, FISITA World Automotive Congress Seoul, Korea 2000.

Jerzy Jantos, DSc, DEng. - Professor in the Faculty of Mechanical Engineering at Opole University of Technology.

Dr hab. inż. Jerzy Jantos, Prof. PO - profesor na Wydziale Mechanicznym Politechniki Opolskiej. e-mail:j.jantos@po.opole.pl

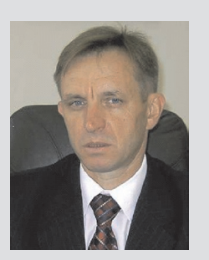

Jarosław Mamala, DEng. - doctor in the Faculty of Mechanical Engineering at Opole University of Technology.

Dr inż. Jarosław Mamala - adiunkt na Wydziale Mechanicznym Politechniki Opolskiej.

e-mail: j.mamala@po.opole.pl
[5] Malewicz K., Prokop S., Mamala J.: Modelowanie charakterystyki eksploatacyjnej silnika o zapłonie iskrowym, Journal of Kones Powertrain and Transport, European Science Society of Powertrain and Transport Publication, Warszawa 2006, Vol. 13, No. 1.

[6] Mamala J., Brol S., Jantos J.: The estimation of the engine power with use of an accelerometer, SAE 2010 Word Congress, USA 2010, Detroit, SAE paper nr 2010-01-0929.

[7] Mamala J., Jantos J., Brol S., Korniak J.: Diagnostics of the Drivetrain in a Passenger Car, Proceedings the 10th International Symposium on Advanced Vehicle Control, AVEC2010 in Loughborough UK.

[8] Miałkowski P., Wendeker M.: Analiza i synteza prędkości kątowej wału korbowego tłokowego silnika spalinowego. Politechnika Lubelska, IV Międzynarodowa Konferencja „Badania symulacyjne w technice samochodowej”, Kazimierz Dolny 1993.

[9] Siłka W.: Teoria ruchu samochodu, WNT, Warszawa 2002, s. 183.

[10] Merkisz J., Mazurek S., Pielecha J.: Pokładowe urządzenia rejestrujące w samochodach, Wydawnictwo Politechniki Poznańskiej, Poznań 2007.

Sebastian Brol, DEng. - Assistant Professor of Mechanical Engineering at Opole University of Technology.

Dr inż. Sebastian Brol - adiunkt na Wydziale Mechanicznym Politechniki Opolskiej.

e-mail: s.brol@po.opole.pl

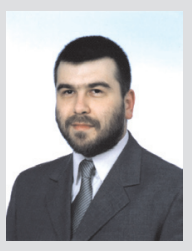

